\title{
A Role for p27/Kip1 in the Control of Cerebellar Granule Cell Precursor Proliferation
}

\author{
Kazuhiro Miyazawa,, ${ }^{1,2}$ Toshiyuki Himi, ${ }^{3}$ Veronica Garcia, ${ }^{3}$ Hisakazu Yamagishi, ${ }^{2}$ Shigeaki Sato, ${ }^{1}$ and \\ Yasuki Ishizaki ${ }^{1}$ \\ 1 Department of Hygiene, Kobe University School of Medicine, Chuo-ku, Kobe 650-0017, Japan, 2Department of Surgery, \\ Kyoto Prefectural University of Medicine, Kamigyo-ku, Kyoto 602-0841, Japan, and ${ }^{3}$ Department of Physiological \\ Chemistry, Postgraduate School, Tokyo Medical and Dental University, Bunkyo-ku, Tokyo 113-8549, Japan
}

During development, control of proliferation of neuronal precursor cells plays a crucial role in determining the number of neurons. Proliferation is driven by mitogens, but how it is terminated remains a mystery. In this study, we examined the role of cyclindependent kinase inhibitors in the control of proliferation of cerebellar granule cell precursors (GCPs). Among the inhibitors we examined, only p27/Kip1 (p27) was expressed at significant levels in cells of the granule cell lineage in the developing and adult cerebellum. In developing cerebella, p27 was expressed in the external germinal layer (the deeper regions), the molecular layer, and the granule layer. In adult cerebella, p27 was expressed in the cells of the granule layer. We isolated and purified GCPs from cerebella of developing mice and examined their bromodeoxyuridine (BrdU) uptake and p27 expression at various times. We found that there was an inverse correlation between BrdU uptake and p27 expression. Even in the presence of saturating amounts of Sonic hedgehog, a potent mitogen, the cells eventually stopped dividing and differentiated, expressing p27 strongly. We also examined mice in which one or both copies of the p27 gene have been inactivated by targeted gene disruption and found that their cerebella were larger than those of wild-type mice. In cell cultures, GCPs prepared from p27-deficient mice showed enhanced proliferation compared with GCPs from wildtype mice. Taken together, these results suggest that there is an intracellular mechanism that stops GCP division and causes GCPs to differentiate and that p27 is part of this mechanism.

Key words: cyclin-dependent kinase inhibitor; p27; cerebellum; cerebellar granule cells; proliferation; cell cycle
Granule cells are generated on the outside of the cerebellum in a region known as the external germinal layer (EGL). In rodents, cells in the EGL proliferate rapidly for 2-3 weeks after birth, generating a large pool of granule cell precursors (GCPs). Developing GCPs then exit the cell cycle, extend axons, and migrate inward to their final destination, the granule layer (GL) (Hatten and Heintz, 1995; Altman and Bayer, 1996). The steps in granule cell differentiation have been well characterized, but the mechanism that controls the proliferation of GCPs remains a mystery. Although it has been suggested that Purkinje cells are required for GCP proliferation (Wetts and Herrup, 1983; Sonmez and Herrup, 1984; Herrup and Sunter, 1987; Vogel et al., 1989; Smeyne et al., 1995; Mullen et al., 1997), it is not known how Purkinje cells stimulate GCP proliferation. Recently, Wechsler-Reya and Scott (1999), Wallace (1999), and Dahmane and Altaba (1999) demonstrated that Purkinje cell-derived Sonic hedgehog (Shh) is a potent mitogen for GCPs. We still do not know, however, what causes GCPs to stop dividing. In the case of oligodendrocytes, we know that p27/Kip1 (p27), a cyclin-dependent protein kinase (Cdk) inhibitor, plays a crucial role in the mechanism whereby oligodendrocyte precursor cells exit the cell cycle (Casaccia-Bonnefil et al., 1997; Durand et al., 1997, 1998).

The eucaryotic cell cycle is controlled by a family of Cdks, which are activated cyclically to trigger the various phases of the cell cycle at the right time and in the right sequence (Sherr, 1994; Lees, 1995; Morgan, 1995). Cdk activity is regulated by various proteins, in-

Received Jan. 12, 2000; revised May 17, 2000; accepted May 19, 2000.

This work was supported by a Grant-in-Aid for Scientific Research on Priority Areas from the Ministry of Education, Science, Sports, and Culture, Japan, by a grant from the Sankyo Foundation of Life Science, and by a grant from the Life Science Foundation of Japan. We thank Nippon Roche for supplying p27-deficient mice and Biogen for a recombinant amino-terminal active fragment of Shh (Shh-N). We also thank Dr. Anne Lawrence and Prof. Martin Raff for helpful comments on this manuscript.

Correspondence should be addressed to Yasuki Ishizaki, Department of Hygiene, Kobe University School of Medicine, Kusunokicho 7-5-1, Chuo-ku, Kobe 650-0017, Japan. E-mail: ishizaki@kobe-u.ac.jp.

Copyright (C) 2000 Society for Neuroscience $0270-6474 / 00 / 205756-08 \$ 15.00 / 0$ cluding cyclins that activate Cdks, kinases and phosphatases that activate or inhibit Cdks (Lees, 1995; Morgan, 1995), and Cdk inhibitors that block the assembly or activity of cyclin-Cdk complexes (Sherr and Roberts, 1995). Two families of Cdk inhibitors have been identified in mammalian cells. The Cip-Kip family includes p21/Cip1 (p21), p27/Kip1 (p27), and p57/Kip2 (p57). The Ink4 family includes p16/Ink4a (p16), p15/Ink4b (p15), p18/Ink4c (p18), and p19/Ink4d (p19) (Sherr and Roberts, 1995). These proteins inhibit the various cyclin-Cdk complexes that control G1 progression and entry into $\mathrm{S}$ phase, and their overexpression in various cell lines arrests the cell cycle in G1 (Sherr and Roberts, 1995). Moreover, some Cdk inhibitors are upregulated when developing cells exit the cell cycle (Matsuoka et al., 1995; Parker et al., 1995; Harper and Elledge, 1996), raising the possibility that they play a role in stopping the cycle at the appropriate time.

In the present study we examined the role of $\mathrm{Cdk}$ inhibitors in the control of GCP proliferation. We found that p27 was present in the EGL and in the GL of the developing cerebellum. Cells in the deeper zone of the EGL expressed p27 more strongly than did cells in the more superficial zone, suggesting that p27 accumulates in GCPs as they proliferate. We also observed an inverse correlation between GCP proliferation and their level of p27 expression in vitro. GCPs from p27-deficient mice showed enhanced proliferation in culture as compared to GCPs from wild-type mice.

\section{MATERIALS AND METHODS}

Animals and materials. C57BL/6 mice were purchased from SLC (Hamamatsu, Japan). The p27-deficient mice (Nakayama et al., 1996) were donated by Nippon Roche (Kamakura, Japan) and bred in the animal facility at Kobe University School of Medicine. Approval for these experiments was obtained from the Kobe University Ethics Committee. The recombinant amino terminal-active fragment of Shh (Shh-N) was a gift from Biogen. All other chemicals were from Sigma (St. Louis, MO) unless indicated otherwise.

Cresyl violet acetate staining procedure. Postnatal day 16 (P16) and P21 mice were anesthetized with ether and perfused with $4 \%$ paraformaldehyde. The brains were removed from the skull, cut into blocks, and fixed in $4 \%$ paraformaldehyde at $4^{\circ} \mathrm{C}$ for $3 \mathrm{~d}$. Then the fixative was replaced by water, and the blocks were dehydrated through a series of ethanol in water, 
followed by xylene. The blocks were then embedded in paraffin and cut sagittally into $4-\mu \mathrm{m}$-thick sections. The sections were stained with $0.1 \%$ cresyl violet acetate for $5 \mathrm{~min}$ and examined in a Leica DM-IRB microscope equipped with a digital camera (Fuji Fujix HC-2500). We measured the areas of the EGL and GL in digitized images of the medial sections using the NIH Image 1.62 image analysis program on a Macintosh computer.

Expression of Cdk inhibitors in the cerebellum. P7 mice were anesthetized with ether and perfused with $4 \%$ paraformaldehyde. The cerebella were removed from the skulls, fixed in ice-cold $4 \%$ paraformaldehyde for $1 \mathrm{hr}$ and then soaked in $30 \%$ sucrose in PBS overnight at $4^{\circ} \mathrm{C}$. The cerebella were then frozen in O.C.T. compound (Miles, West Haven, CT) and cut into $7-\mu \mathrm{m}$-thick sagittal sections on a cryostat. The sections were collected onto precoated slides and left at room temperature for $30 \mathrm{~min}$ to air dry. The sections were stored at $-80^{\circ} \mathrm{C}$ until they were stained.

Next the sections were microwaved for $15 \mathrm{~min}$ in $10 \mathrm{~mm}$ citrate buffer, $\mathrm{pH}$ 6.0, and incubated in blocking buffer (50\% normal goat serum solution containing $150 \mathrm{~mm} \mathrm{NaCl}, 50 \mathrm{~mm}$ Tris, $\mathrm{pH}$ 7.4, $100 \mathrm{~mm}$ L-lysine, and $0.4 \%$ Triton X-100) for $30 \mathrm{~min}$ to block nonspecific binding. The sections were then incubated with a mixture of an anti-p27 monoclonal antibody (Transduction Laboratories, Lexington, KY; diluted 1:100) and an antiproliferating cell nuclear antigen (PCNA) polyclonal antibody (Santa Cruz Biochemicals, Santa Cruz, CA; diluted 1:100) for $2 \mathrm{hr}$, washed, incubated with biotinylated goat anti-mouse Ig (Amersham, Arlington Heights, IL; diluted 1:100) for $1 \mathrm{hr}$, washed again, and then incubated with a mixture of Texas Red-coupled streptavidin (Amersham; diluted 1:100) and fluorescein-coupled goat anti-rabbit Ig (Amersham; diluted 1:100) for $1 \mathrm{hr}$. We also stained other sections with anti-p18, anti-p21, anti-p27, anti-p57, and anti-cyclin D1 polyclonal antibodies (all from Santa Cruz; diluted $1: 100$ ) using the rabbit ABC staining system (Santa Cruz), following the protocol supplied by the manufacturer. The stained sections were covered with PermaFluor (Immunon, Pittsburgh, PA) and glass coverslips, which were sealed with nail polish. The sections were then viewed either in a Bio-Rad MRC-1024 confocal, laser scanning fluorescence microscope or in an Olympus BX50 light microscope.

Preparation of GCP cultures. Cerebellar GCPs were prepared according to Baptista et al. (1994), with minor modifications. Cerebella from P3, P7, P11, or P14 mice were cut into two or three pieces with scalpels and incubated at $37^{\circ} \mathrm{C}$ for $20 \mathrm{~min}$ in Earle's balanced salt solution (Life Technologies, Gaithersburg, MD) containing $0.435 \%$ papain (Worthington, Lakewood, NJ), $0.5 \mathrm{~mm}$ EDTA, $26 \mathrm{~mm}$ sodium bicarbonate, $25 \mathrm{~mm}$ glucose, $0.05 \%$ DNase I (Worthington), and $1 \mathrm{~mm}$ cysteine. Digestion was stopped by adding EBSS containing $0.2 \%$ ovomucoid and $0.1 \%$ bovine serum albumin (BSA). The tissue was triturated with a Pasteur pipette to obtain a suspension of single cells. The cells were then centrifuged, resuspended in PBS containing $0.05 \%$ DNase I, loaded onto a step gradient of $35 \%$ and $60 \%$ Percoll (Pharmacia, Uppsala, Sweden), and centrifuged at $3000 \mathrm{rpm}$ for $20 \mathrm{~min}$ at room temperature. The cells at the $35 / 60 \%$ interface were collected using a fine-polished Pasteur pipette, washed in PBS containing $2 \mathrm{mM}$ EDTA, and resuspended in DMEM/F-12 (Life Technologies) containing 2\% BSA. The cells were purified further by discarding those cells that adhered to tissue culture dishes coated with 50 $\mu \mathrm{g} / \mathrm{ml}$ poly-D-lysine (PDL) during two $30 \mathrm{~min}$ incubations. The nonadhering cells were resuspended in DMEM/F-12 containing $2 \%$ BSA, $5 \mu \mathrm{g} / \mathrm{ml}$ insulin, $100 \mu \mathrm{g} / \mathrm{ml}$ apotransferrin, $0.04 \mu \mathrm{g} / \mathrm{ml}$ sodium selenite, 0.062 $\mu \mathrm{g} / \mathrm{ml}$ progesterone, and $16 \mu \mathrm{g} / \mathrm{ml}$ putrescine, at a density of $4-6 \times 10^{6}$ cells $/ \mathrm{ml}$. In some experiments, Shh-N $(3-10 \mu \mathrm{g} / \mathrm{ml})$ was added to the culture medium. Then the cells were plated out in eight-well Lab-Tek chamber slides $(200 \mu \mathrm{l} /$ well; Permanox slide, Nunc Inc., Naperville, IL) or 60 -well Terasaki microculture plates $(10 \mu \mathrm{l} /$ well; Nunc), both coated with $50 \mu \mathrm{g} / \mathrm{ml}$ PDL. The cells were cultured in a humidified atmosphere of $5 \% \mathrm{CO}_{2}$ and $95 \%$ air at $37^{\circ} \mathrm{C}$.

Proliferation of cultured GCPs. To label cells in $\mathrm{S}$ phase in vitro, purified GCPs were incubated in $10 \mu \mathrm{M}$ bromodeoxyuridine (BrdU; Boehringer Mannheim, Mannheim, Germany) for various times after plating. Then the cells were fixed in $70 \%$ ethanol in $50 \mathrm{~mm}$ glycine buffer, $\mathrm{pH} 2.0$, at $-20^{\circ} \mathrm{C}$ for $20 \mathrm{~min}$. The cells were then incubated with an anti-BrdU monoclonal antibody (Boehringer Mannheim; diluted 1:10), followed by a fluoresceincoupled goat anti-mouse Ig (Boehringer Mannheim; diluted 1:10), and then $4 \mu \mathrm{g} / \mathrm{ml}$ propidium iodide. The cells were viewed in a Bio-Rad MRC-1024 confocal, laser scanning fluorescence microscope. At least 2000 cells were checked in each sample, and the fraction of BrdU-positive cells was determined. In some experiments, we double-stained GCPs with an anti-BrdU monoclonal antibody and an anti-glial fibrillary acidic protein (GFAP) polyclonal antibody (Dako, Glostrup, Denmark; diluted 1:100) to test for selective proliferation of contaminating glia. The BrdU-labeled cells were fixed in $70 \%$ ethanol in $50 \mathrm{~mm}$ glycine buffer, $\mathrm{pH} 2.0$, at $-20^{\circ} \mathrm{C}$ for $20 \mathrm{~min}$. The cells were then incubated with a mixture of an anti-BrdU monoclonal antibody and an anti-GFAP polyclonal antibody for $1 \mathrm{hr}$, washed, incubated with biotinylated goat anti-rabbit Ig (Amersham; diluted 1:100) for $1 \mathrm{hr}$, washed again, and then incubated with a mixture of Texas Red-coupled streptavidin (Amersham; diluted 1:100) and fluorescein-coupled goat antimouse Ig (Amersham; diluted 1:100) for $1 \mathrm{hr}$. The cells were viewed in a Bio-Rad MRC-1024 confocal, laser scanning fluorescence microscope. We also assessed the proliferation of cultured GCPs by measuring the mitotic index using Mitotic Protein Monoclonal \#2 (MPM-2) antibody (Upstate Biotechnology, Lake Placid, NY), which specifically labels cells in the M phase. GCPs were cultured in the presence or absence of Shh-N $(3 \mu \mathrm{g} / \mathrm{ml})$ for various times in Lab-Tek chamber slides and then fixed in $4 \%$ paraformaldehyde for $10 \mathrm{~min}$. The cells were then washed in PBS, permeabilized with ice-cold methanol for $6 \mathrm{~min}$, washed twice in PBS, and incubated in blocking buffer for 30 min to block nonspecific binding. Next the cells were incubated with the MPM-2 antibody (diluted 1:100) for $2 \mathrm{hr}$, followed by a fluorescein-coupled goat anti-mouse Ig antibody (Amersham; diluted 1:100) for $1 \mathrm{hr}$. Propidium iodide was used as a counterstain. The stained cells were covered with PermaFluor and a glass coverslip, which was sealed with nail polish. The cells were viewed in a Bio-Rad MRC-1024 confocal, laser scanning fluorescence microscope. At least 2000 cells were checked in each sample, and the fraction of MPM-2-positive cells was determined. Moreover, we assessed the proliferation of cultured GCPs by directly counting the number of cells during the culture period. We plated GCPs from P11 p27+/+ or p27-/- mice in Terasaki microculture plates and took photomicrographs of each well 2, 24, 48, and $72 \mathrm{hr}$ after plating. We selected six areas within each well (which contained at least 4000 cells $2 \mathrm{hr}$ after plating) and counted the number of live (phase-bright) cells within each area at each time point. The number of live cells at each time point is expressed relative to the number of cells present in the identical area 2 hr after plating. The results are given as the mean \pm SD of six areas. In total, we performed this experiment twice and obtained similar results.

Expression of p27 by cultured GCPs. GCPs were cultured for various times in Lab-Tek chamber slides and then fixed in $4 \%$ paraformaldehyde for $5 \mathrm{~min}$. The cells were then washed in PBS and incubated in blocking buffer for $30 \mathrm{~min}$ to block nonspecific binding. Next the cells were incubated with an anti-p27 polyclonal antibody (Santa Cruz; diluted 1:100) for $2 \mathrm{hr}$, followed by a fluorescein-coupled goat anti-rabbit Ig antibody (Cappel, Aurora, OH; 1:100) for $1 \mathrm{hr}$. Propidium iodide was used as a counterstain. The stained cells were covered with PermaFluor and a glass coverslip, which was sealed with nail polish. They were viewed in a Bio-Rad MRC-1024 confocal, laser scanning fluorescence microscope. We observed that most of the cells were readily classified as weakly stained or strongly stained; very few cells showed an intermediate degree of staining. Therefore, we judged each cell by eye as being weakly stained (p27 negative) or strongly stained (p27 positive) without quantifying the degree of staining. At least 2000 cells were assessed in each sample, and the fraction of p27-positive cells was determined.

Cultures of reaggregated GCPs. To examine the proliferative capacity of GCPs cultured in cellular reaggregates, single-cell suspensions of GCPs were prepared from P10 mice and plated into uncoated plastic wells of Falcon 24-well tissue culture plates in the presence or absence of Shh-N $(3 \mu \mathrm{g} / \mathrm{ml})$. The cells formed large cellular reaggregates in $12 \mathrm{hr}$ under these conditions (Gao et al., 1991). For experiments examining p27 expression by GCPs in reaggregates, we transferred the reaggregates to PDL-coated eight-well Lab-Tek chamber slides at 12, 60, and $132 \mathrm{hr}$ and cultured them for a further $12 \mathrm{hr}$ before fixation in $4 \%$ paraformaldehyde and processing for immunostaining as described above. For BrdU assay, the cellular reaggregates were transferred to PDL-coated chamber slides at 24, 72, 120, and $240 \mathrm{hr}$ and labeled with $\mathrm{BrdU}$ for $24 \mathrm{hr}$. Some reaggregates were labeled for the period $0-24 \mathrm{hr}$ after plating, by adding BrdU to the cultures just after plating and transferring the reaggregated cells in the medium containing BrdU to PDL-coated chamber slides $12 \mathrm{hr}$ later. The reaggregates were cultured for an additional $12 \mathrm{hr}$ to allow them to adhere to the PDL-coated plastic. The reaggregates were then washed once in PBS, fixed in $70 \%$ ethanol in $50 \mathrm{~mm}$ glycine buffer, $\mathrm{pH} 2.0$, at $-20^{\circ} \mathrm{C}$ for $20 \mathrm{~min}$, and processed for immunostaining as described above. In some experiments, we double-stained the reaggregates with an anti-p27 polyclonal antibody and an anti-BrdU monoclonal antibody.

3-(4,5-Dimethylthiazol-2-yl)-2,5-diphenyltetrazolium bromide survival assay. GCPs from P11 p27+/+, p27+/-, or p $27-/-$ mice were plated in Terasaki microculture plates, and the percentage of surviving cells was assessed using the 3-(4,5-dimethylthiazol-2-yl)-2,5-diphenyltetrazolium bromide (MTT) assay as described previously (Mosmann 1983; Ishizaki et al., 1993). Viable cells cleave the tetrazolium ring of MTT, thus creating a visible dark blue formazan reaction product, whereas dead cells remain uncolored. At $0,1,2$, and $3 \mathrm{~d}$, we added MTT to the cultures, randomly selected four areas of each well, counted all the cells (dead and live cells) within each area (at least 400 cells were within each area), and calculated the fraction of live cells.

Terminal deoxynucleotidyl transferase-mediated biotinylated dUTP nick end labeling. Cell death in the developing cerebellum was assessed by a modified version (Ishizaki et al., 1998) of Gavrieli's terminal deoxynucleotidyl transferase-mediated biotinylated dUTP nick end labeling (TUNEL) technique (Gavrieli et al., 1992). Frozen sections of cerebella from P7 mice were permeabilized in $0.1 \%$ Triton $\mathrm{X}-100$ and then treated with proteinase $\mathrm{K}(20 \mu \mathrm{g} / \mathrm{ml})$ for $20 \mathrm{~min}$ at $37^{\circ} \mathrm{C}$. After extensive washing, the sections were preincubated for $10 \mathrm{~min}$ at room temperature in the reaction buffer for terminal deoxynucleotidyl transferase supplied by Boehringer Mannheim. The reaction was started by removing the preincubation buffer and adding the reaction mixture, which contained $500 \mathrm{U} / \mathrm{ml}$ terminal deoxynucleotidyl transferase, $2.5 \mathrm{~mm} \mathrm{CoCl}_{2}$, and $40 \mu \mathrm{M}$ biotinylated dUTP. Control sections were incubated in the reaction mixture without terminal deoxynucleotidyl transferase. After $1 \mathrm{hr}$ at $37^{\circ} \mathrm{C}$, the reaction was terminated by adding 300 $\mathrm{mm} \mathrm{NaCl}$ and $30 \mathrm{~mm}$ sodium citrate. The sections were incubated in $2 \%$ BSA in PBS for $10 \mathrm{~min}$ and then in streptavidin-fluorescein (diluted 1:100, Amersham) for $60 \mathrm{~min}$ in the dark. After extensive washing in PBS, the 

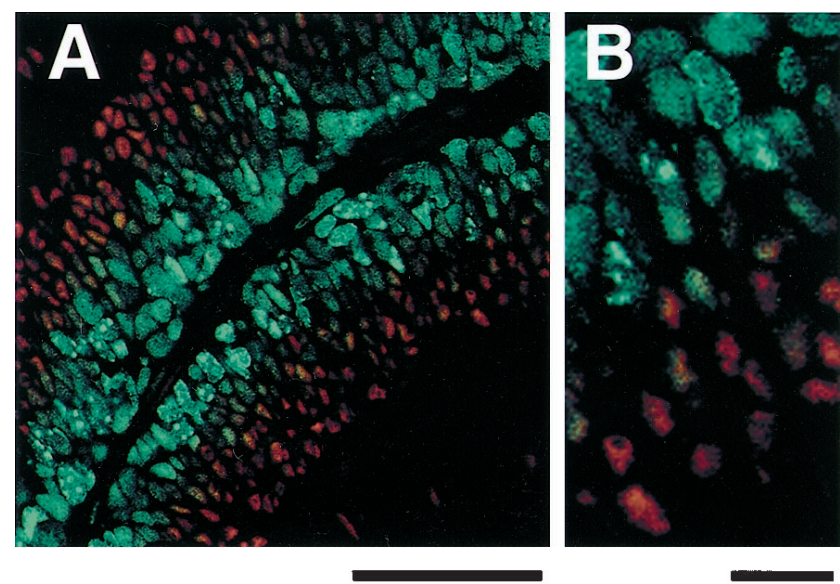

Figure 1. The expression of p27 and PCNA in the developing cerebellum. $A$, The cerebellum of a $\mathrm{P} 7$ mouse was fixed, sectioned sagittally, and double-stained with an anti-p27 antibody (red) and an anti-PCNA antibody (green). $B$, Higher magnification of the EGL shown in $A$; note that the cells in the middle of the EGL express both p27 and PCNA. Scale bars: $A, 50$ $\mu \mathrm{m}: B, 10 \mu \mathrm{m}$.

sections were covered with PermaFluor and with glass coverslips, which were sealed with nail polish. The sections were viewed in a Bio-Rad MRC-1024 confocal, laser scanning fluorescence microscope.

\section{RESULTS}

\section{Expression of p27 in the cerebellum}

To help determine whether p27 plays a role in regulating GCP proliferation, we double-stained frozen sections of P7 mouse cerebella with an anti-p27 monoclonal antibody and an anti-PCNA polyclonal antibody. In addition to Purkinje cells (data not shown), which were previously reported to express p27 (Watanabe et al., 1998), the cells in the inner two-thirds of the EGL were positive for p27; those in the superficial areas expressed p27 weakly, whereas those in the deeper areas expressed p27 strongly (Fig. 1). By contrast, it was the cells in the outer two-thirds of the EGL that expressed PCNA, as reported previously (Shambaugh et al., 1996), indicating that these cells are in the $\mathrm{S}$ phase of the cell cycle. Thus the cells in the middle of the EGL expressed both p27 and PCNA (Fig. $1 B$ ). Cells in the molecular layer (Fig. $1 A$ ), and cells in the GL (data not shown) also expressed p27, but not PCNA, indicating that they and the cells in the inner one-third of the EGL were postmitotic. In adult mice, granule cells in the GL and Purkinje cells expressed p27 strongly (data not shown). These findings are significantly different from those of a previous study, which reported that p27 was expressed primarily by Purkinje cells and not by the GCPs in the EGL (Watanabe et al., 1998), so we tried two different antibodies (a monoclonal antibody and a polyclonal antibody); the results that we obtained with the two antibodies were similar. These results suggest that GCPs begin to accumulate p27 before they exit the cell cycle and that the level of p27 expression remains high in mature granule cells in the adult cerebellum. We examined the expression of other Cdk inhibitors, including p18, p21, and p57, in the developing cerebella, using specific antibodies against each of them, but only the antibody to p21 resulted in significant staining (data not shown). p21 was expressed predominantly by the Purkinje cells, as reported previously (Watanabe et al., 1998). We also examined the expression of cyclin D1 in the developing cerebellum and observed that the cells in the outer two-thirds of the EGL expressed cyclin D1, whereas cells in the deeper part of the EGL, in the molecular layer, and in the GL lacked cyclin D1 (data not shown), as reported previously (Shambaugh et al., 1996; Watanabe et al., 1998). This result suggests that cyclin D1 disappears in postmitotic cells. Taken together, these results suggest that p27 plays an important role in the exiting of GCPs from the cell cycle and in preventing mature granule cells from dividing.
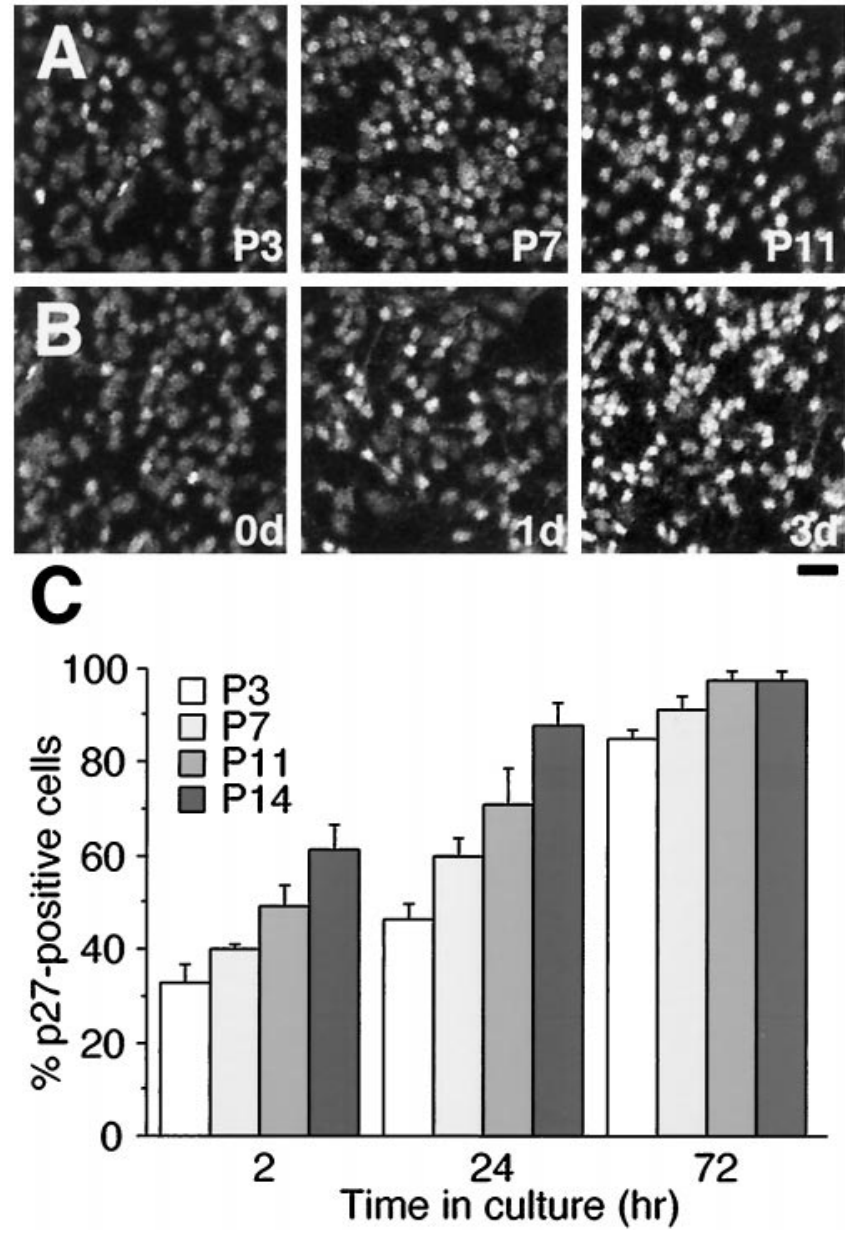

Figure 2. Expression of $\mathrm{p} 27$ in GCPs in culture. GCPs were prepared from P3, P7, P11, and P14 mice, cultured for various times, fixed, and stained using an anti-p27 antibody. We judged by eye whether each cell was weakly stained (p27 negative) or strongly stained ( 27 positive) and determined the percentage of p27-positive GCPs $(A, B)$. A, GCPs from P3, P7, and P11 mice were fixed and stained $2 \mathrm{hr}$ after plating. $B$, GCPs from P3 mice were cultured for $2 \mathrm{hr}(0 d), 1 \mathrm{~d}(1 d)$, and $3 \mathrm{~d}(3 d)$ before staining. Scale bar, 50 $\mu \mathrm{m}$. $C$, The results (means $\pm \mathrm{SD}$ ) of four samples in a single experiment, which were confirmed by two additional experiments.

\section{Expression of p27 by cultured GCPs}

When we cultured GCPs from cerebella of P3, P7, P11, and P14 mice at a high density in serum-free medium, most of the cells showed strong or weak, but not intermediate, p27 staining (Fig. $2 A, B)$. Two hours after plating, $\sim 60 \%$ of the GCPs from $\mathrm{P} 14$ mice were p27 positive, whereas only $30 \%$ of the cells from P3 mice were p27 positive. The proportion of p27-positive cells increased with the time in culture: $3 \mathrm{~d}$ after plating, nearly all of the cells from P11 or P14 mice, and $>80 \%$ of the cells from P3 or P7 mice, strongly expressed p27 (Fig. 2C). All of the p27-positive cells had neurites $3 \mathrm{~d}$ after plating and showed morphological features that are characteristic of mature granule cells in culture (data not shown).

\section{Proliferation of cultured GCPs}

During the first day of culture, the proportion of GCPs that incorporated BrdU was $\sim 65,53,36$, and $25 \%$ for cells from P3, P7, P11, and P14 mice, respectively (Fig. 3). During the second day of culture, however, only $\sim 30 \%$ of GCPs from P3 mice incorporated BrdU, and the percentage was $<10$ for GCPs from older animals. During the fourth day of culture, only $2 \%$ of GCPs from P3 mice, and none of the GCPs from older animals, incorporated BrdU. Thus it was demonstrated that there is an inverse correlation between p27 expression and BrdU incorporation by cultured GCPs. We double-stained some BrdU-labeled cells with an anti- 

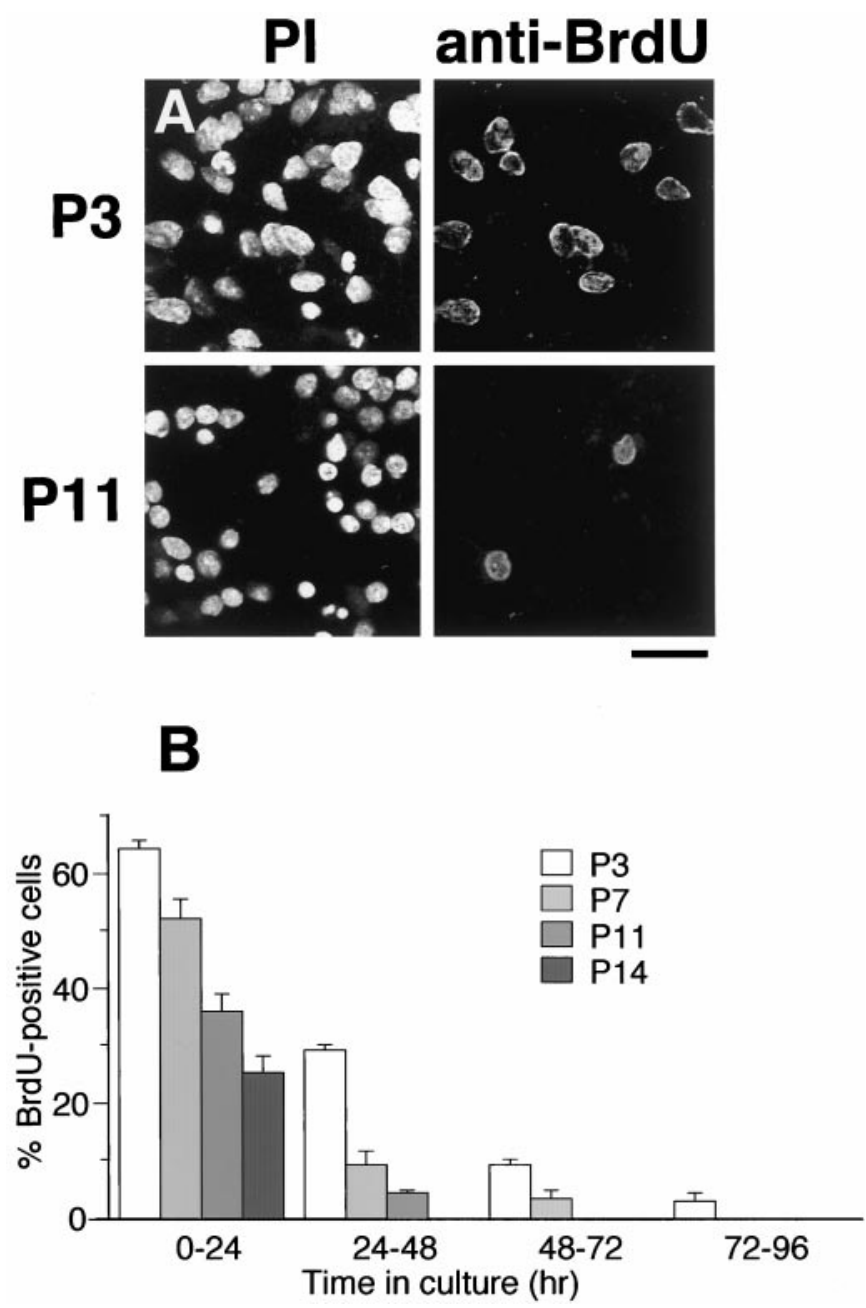

Figure 3. Proliferation of GCPs in culture. GCPs were prepared from P3, P7, P11, and P14 mice, incubated with BrdU for the period 0-24, 24-48, $48-72$, or $72-96 \mathrm{hr}$ after plating, and stained with propidium iodide $(P I)$ and an anti-BrdU (anti-BrdU) antibody. The percentage of BrdU-positive cells was determined by counting. $A$, GCPs from P3 and P11 mice that were incubated with BrdU from 24 to $48 \mathrm{hr}$ after plating are shown. Scale bar, 20 $\mu \mathrm{m}$. $B$, The results (means $\pm \mathrm{SD}$ ) of four samples in a single experiment, which were confirmed by three additional experiments.

BrdU antibody and an anti-GFAP (a marker for astroglial cells) antibody to test for selective proliferation of any contaminating glial cells and found that almost all of the BrdU-positive cells were GFAP negative (data not shown).

Adding Shh-N (3-10 $\mu \mathrm{g} / \mathrm{ml})$, the amino-terminal active fragment of Shh, significantly increased the proportion of GCPs that incorporated BrdU (compare Figs. $3 B$ and 4), confirming previous reports (Dahmane and Altaba, 1999; Wallace, 1999; WechslerReya and Scott, 1999). Even in the presence of Shh-N, however, BrdU incorporation by GCPs from P3 mice stopped on approximately the 11th day of culture. GCPs from P7 mice stopped incorporating BrdU on approximately the seventh day of culture, and GCPs from P10 mice stopped between the fourth and seventh days of culture (Fig. 4A). We also assessed the proliferation of cultured GCPs from P10 mice by measuring the mitotic index with an antibody that specifically labels cells in the $\mathrm{M}$ phase. The mitotic index was not affected by incubating the cells with Shh-N for $2 \mathrm{hr}$ (Fig. 4B). Thereafter, Shh-N increased the mitotic index significantly, but the mitotic index decreased to near zero at approximately the fourth day of culture, even in the presence of Shh-N. The percentage of $\mathrm{p} 27$-positive cells was not significantly different between Shh-N-treated and control cultures of GCPs from P3, P7, or P11 mice for each time point examined up to $96 \mathrm{hr}$, when most
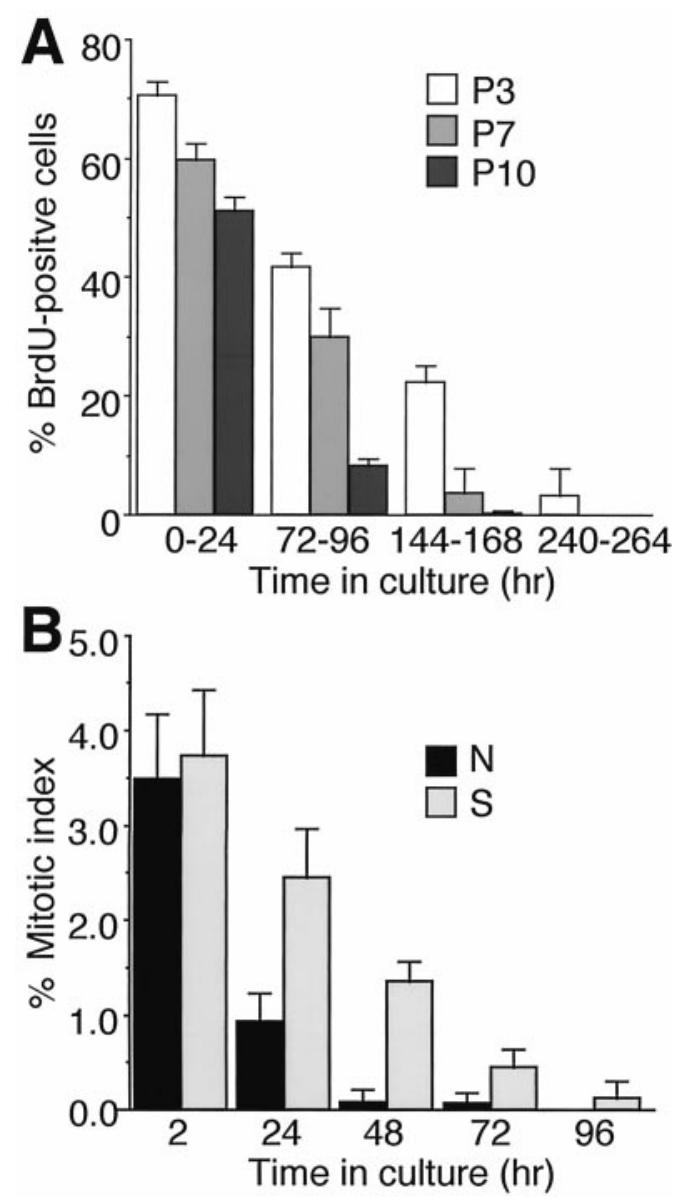

Figure 4. Effect of Shh-N on GCP proliferation in culture. $A$, GCPs were prepared from P3, P7, and P10 mice, cultured in the presence of Shh-N (3 $\mu \mathrm{g} / \mathrm{ml})$, incubated with BrdU for the period $0-24,72-96,144-168$, or 240-264 hr after plating, and stained with propidium iodide and an antiBrdU antibody. Shh-N was added every fourth day during the culture. The percentage of BrdU-positive cells was determined by counting. The results (means \pm SD) of four samples in a single experiment are shown. We repeated this experiment twice and got similar results. We also tried Shh-N at the concentration of $10 \mu \mathrm{g} / \mathrm{ml}$ and got similar results. $B$, GCPs from P10 mice were cultured in the presence $(S)$ or absence $(N)$ of Shh-N $(3 \mu \mathrm{g} / \mathrm{ml})$ for various times in Lab-Tek chamber slides, fixed in $4 \%$ paraformaldehyde, and then stained with propidium iodide and the MPM-2 antibody, which specifically labels cells in $\mathrm{M}$ phase. The mitotic index was determined by counting MPM-2-positive cells. The results represent means $\pm \mathrm{SD}$ of eight samples from a single experiment and were confirmed by two additional experiments.

of the cells expressed p27 strongly whether Shh was present or not (data not shown).

We also examined the proliferative capacity of GCPs from P10 mice cultured in cellular reaggregates. The reaggregated GCPs showed BrdU uptake greater than that of GCPs cultured as a dispersed monolayer (Fig. $5 A$ ). Even in the absence of Shh, $\sim 50 \%$ of aggregated GCPs incorporated BrdU on the first day of culture, and $20 \%$ of them incorporated BrdU on the second day of culture. After $4 \mathrm{~d}$, however, BrdU uptake decreased to near zero even in reaggregated cell cultures. In the presence of Shh, aggregated GCPs showed BrdU uptake greater than that of GCPs cultured as a dispersed monolayer for the first $4 \mathrm{~d}$ of culture, but the cells in most of the reaggregates did not show BrdU uptake after $5 \mathrm{~d}$ of culture. The percentage of p27-positive cells in the reaggregates was smaller than in the monolayer cultures at $24 \mathrm{hr}$ after plating (compare Figs. $2 C$ and $5 B$ ); however, the percentage increased gradually, and most of GCPs in the reaggregates were p27-positive on the sixth day of culture (Fig. $5 B$ ). In the cultures treated with Shh-N for $>5 \mathrm{~d}$, we occasionally observed reaggregates containing many BrdU-positive cells, which were clustered 

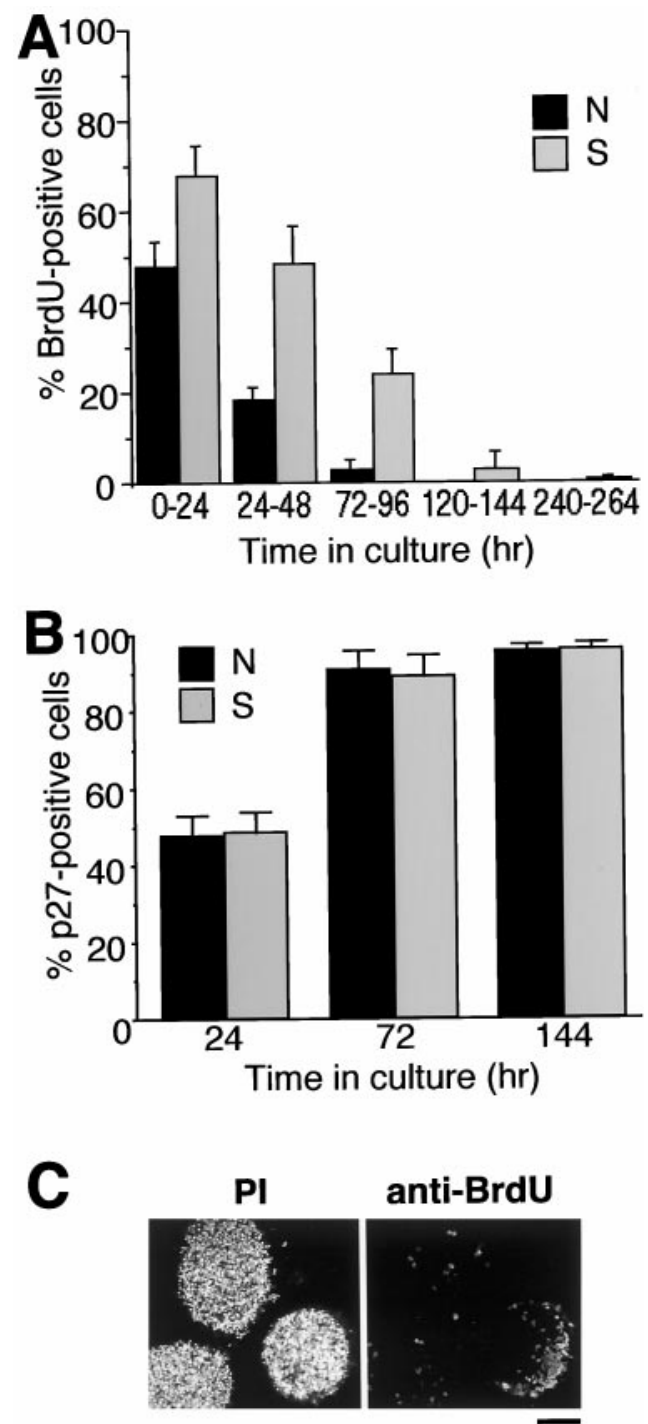

Figure 5. Proliferation of GCPs in reaggregate cultures. A, GCPs from P10 mice were cultured in cellular reaggregates in the presence $(S)$ or absence $(N)$ of Shh-N $(3 \mu \mathrm{g} / \mathrm{ml})$, incubated with BrdU for the period 0-24, 24-48, 72-96, 120-144, or 240-264 hr after plating, and stained with propidium iodide and an anti-BrdU antibody. The percentage of BrdUpositive cells was determined by counting. The results represent means \pm SD of four to eight samples from a single experiment and were confirmed by two additional experiments. $B$, GCPs from P10 mice were cultured in reaggregates in the presence $(S)$ or absence $(N)$ of Shh-N $(3 \mu \mathrm{g} / \mathrm{ml})$ for various times, fixed, and stained using an anti-p27 antibody. The results represent means \pm SD of four to six samples from a single experiment and were confirmed by two additional experiments. $C$, GCPs from P10 mice were cultured in reaggregates in the presence of Shh-N (3 $\mu \mathrm{g} / \mathrm{ml})$, labeled with BrdU for $24 \mathrm{hr}$ on the sixth day of culture, and stained with propidium iodide $(P I)$ and an anti-BrdU (anti-BrdU) antibody. Note that many BrdUpositive cells are clustered together within one of the reaggregates. Scale bar, $50 \mu \mathrm{m}$

together within the reaggregates (Fig. $5 C$ ). When these cells were double-stained with an anti-p27 polyclonal antibody and an antiBrdU monoclonal antibody, most of them were found to express p27 only weakly (data not shown).

\section{Effect of p27 gene inactivation on the developing cerebellum}

Cerebella from p27+/- mice appeared to be larger than those from $\mathrm{p} 27+/+$ mice and smaller than those from $\mathrm{p} 27-/-$ mice (Fig. $6 A-C)$. This result agrees well with previous reports that the p27-/- mouse has multiorgan hyperplasia (Fero et al., 1996; Kiyokawa et al., 1996; Nakayama et al., 1996). Examination of formalin-fixed, paraffin-embedded sections of the cerebella of P16
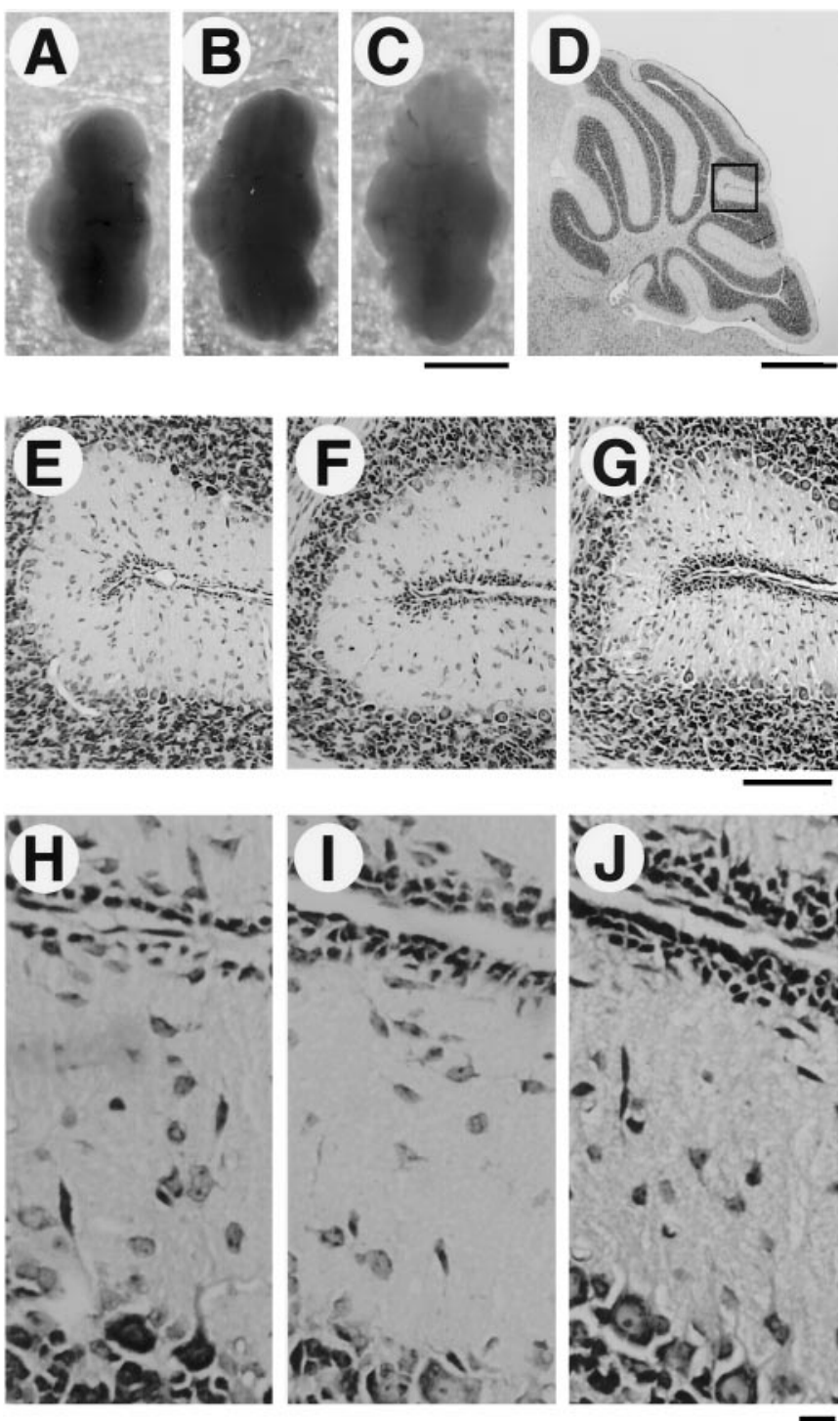

Figure 6. Comparison of cerebella from wild-type $(\mathrm{p} 27+/+), \mathrm{p} 27+/-$, and $\mathrm{p} 27-/-$ mice. $A-C$, The appearance of cerebella from P11 $\mathrm{p} 27+/+$ $(A), \mathrm{p} 27+/-(B)$, and $\mathrm{p} 27-/-(C)$ mice on gross examination. Scale bar, $5 \mathrm{~mm}$. $D-J$, Persistance of the EGL in the cerebella of P16 p27-deficient mice. Brains were dissected from P16 mice, fixed, embedded in paraffin, and cut sagittally into $4-\mu \mathrm{m}$-thick sections. The sections were then stained with $0.1 \%$ cresyl violet acetate. Low magnification of a wild-type cerebellum is shown in $D$ to indicate the location of the region seen in $E-J$. Scale bar, $1 \mathrm{~mm}$. The cerebella were from p27+/+ $(E, H), \mathrm{p} 27+/-(F, I)$, and p27-/- $(G, J)$ mice. Scale bars: $E-G, 100 \mu \mathrm{m} ; H-J, 10 \mu \mathrm{m}$.

mice showed that only a few cells remained in the EGL in p27+/+ mice, whereas many more cells were present in the EGL in p27+/and p $27-/-$ mice (Fig. $6 E-J$ ). When we measured the areas of the EGL and the GL of the cerebella of P16 mice and the area of the GL of the cerebella of P21 mice, we found that the EGL of the P16 p27-/- mice was significantly larger than that of P16 p27+/+ mice and that the GL of the P21 p27-/- mice was significantly larger than that of P21 p27+/+ mice (Table 1). Examination of frozen sections of cerebella after TUNEL labeling showed that although the width of the EGL varied with the p27 genotype (p27-/- > p27+/- > p27+/+; widest to narrowest), the percentage of apoptotic cells in the EGL (the apoptotic cells were mainly in the more superficial zone) and in the GL did not vary with the p27 genotype (data not shown). These results suggest that p27 is involved in the control of GCP proliferation in vivo.

When we isolated and purified GCPs for use in in vitro experiments, the number of GCPs obtained from a p27-/- mouse was always larger than that from a p $27+/-$ or $\mathrm{p} 27+/+$ mouse. The 


\begin{tabular}{|c|c|c|c|}
\hline Age & Layer & $\mathrm{p} 27+/+$ & p27-/- \\
\hline \multirow[t]{2}{*}{ P16 } & EGL & $0.031 \pm 0.009$ & $0.054 \pm 0.016^{*}$ \\
\hline & GL & $1.294 \pm 0.249$ & $1.564 \pm 0.345$ \\
\hline $\mathrm{P} 21$ & GL & $1.352 \pm 0.196$ & $1.603 \pm 0.160^{*}$ \\
\hline
\end{tabular}

The areas of the EGL and the GL were measured in digitized images of the medial sagittal sections of the cerebella from wild-type $(\mathrm{p} 27+/+)$ and $\mathrm{p} 27-/-$ mice using the NIH Image 1.62 image analysis program. The EGL of the P16 p27-/- mice was significantly larger than that of the P16 p $27+/+$ mice $(* p<0.05 ; t$ test), and the GL of the P21 p27-/- mice was significantly larger than that of the P21 p27+/+ mice $\left({ }^{*} p<0.05 ; t\right.$ test $)$. Values are expressed as means \pm SD.

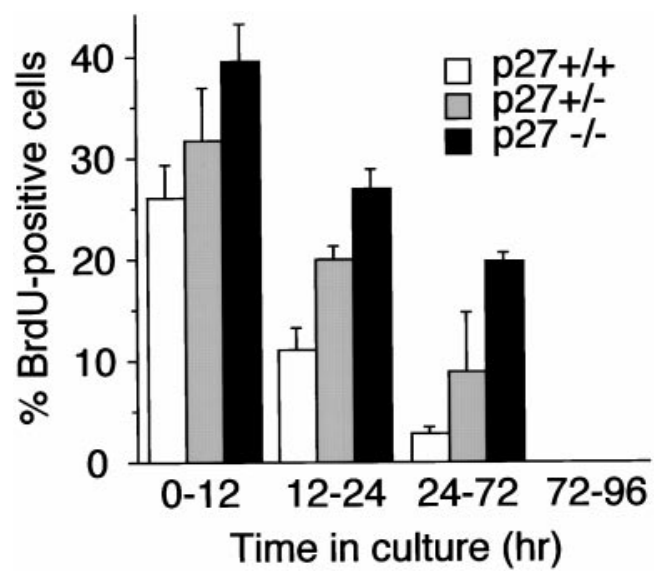

Figure 7. In vitro proliferation of GCPs from p27-deficient and wild-type mice. GCPs were prepared from P11 wild-type (p27+/+), p27+/-, or p $27-/-$ mice, incubated with BrdU for the period $0-12,12-24,24-72$, or $72-96 \mathrm{hr}$ after plating, and stained with propidium iodide and an anti-BrdU antibody. The percentage of BrdU-positive cells was determined by counting. The results represent means $\pm \mathrm{SD}$ of three samples from a single experiment and were confirmed by two additional experiments.

numbers of cells obtained from p27+/+, p27+/-, and p27-/mice were $10.0 \pm 1.3 \times 10^{6}$ cells, $13.4 \pm 0.9 \times 10^{6}$ cells, and $17.2 \pm$ $3.1 \times 10^{6}$ cells, respectively (means $\pm \mathrm{SD}$ of five separate experiments), and they were significantly different $(p<0.05)$ from each other as determined by ANOVA followed by Fisher's exact test. When cultured at a high density in serum-free medium, the percentage of proliferating (BrdU-positive) cells in the GCP preparations from $\mathrm{p} 27+/-$ or $\mathrm{p} 27-/-$ mice was always higher than the percentage in the GCPs from p27+/+ mice (Fig. 7). During the period from the 24 th to the $72 \mathrm{nd}$ hr of culture, nearly $20 \%$ of the p27-/- GCPs and $10 \%$ of the p27+/- GCPs incorporated BrdU, whereas only $2.5 \%$ of the p $27+/+$ GCPs incorporated BrdU. During the $48-72 \mathrm{hr}$ period of the culture, nearly $10 \%$ of p27-/ - cells incorporated BrdU, whereas none of the p27+/- or p $27+/+$ cells incorporated BrdU (data not shown). During the 72-96 hr period of the culture, however, none of the GCPs from p27-/-, p27+/-, or p27+/+ mice incorporated BrdU, and all of the cells showed morphological features characteristic of mature granule cells (data not shown). To confirm that p27-/- cells proliferate more than $27+/+$ cells, we plated GCPs at a high density in Terasaki microculture plates in serum-free medium, photographed the cells in each microwell every $24 \mathrm{hr}$ for $3 \mathrm{~d}$, and counted the number of live (phase-bright) cells in each microwell. The distribution of the cells in each microwell changed so dramatically during the first $24 \mathrm{hr}$ that we could not determine the fate of individual cells during that period. From 2 to $3 \mathrm{~d}$ of culture, however, the cells migrated only a little, and we were able to follow individual cells. During that period we did not see any $27+/+$ GCPs divide, although we often observed dividing p27-/- cells (data not shown). The number of $\mathrm{p} 27+/+$ cells gradually decreased, whereas the number of $\mathrm{p} 27-/-$ cells increased during the first $48 \mathrm{hr}$ of culture (Fig. $8 A$ ). To test the possibility that the
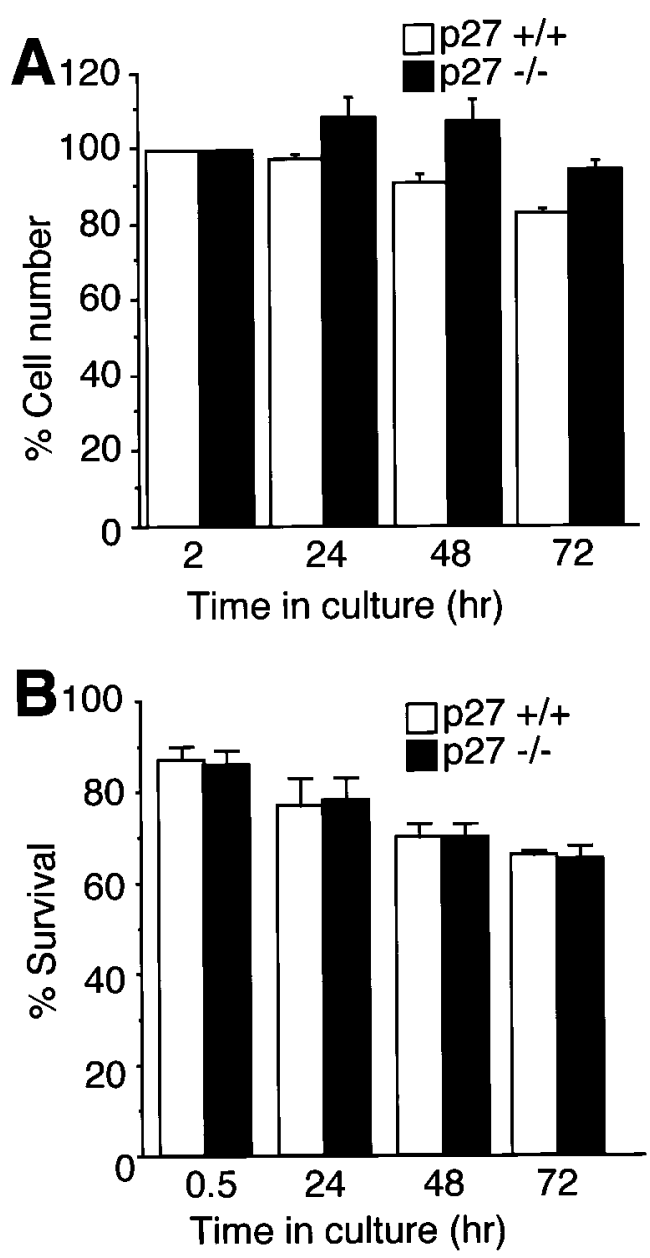

Figure 8. Cell numbers and survival rate in GCP cultures. $A$, We plated GCPs from P11 p27+/+ or p27-/- mice in a Terasaki microculture plate and took photomicrographs of each well at $2 \mathrm{hr}, 24 \mathrm{hr}(1 \mathrm{~d}), 48 \mathrm{hr}(2 \mathrm{~d})$, and $72 \mathrm{hr}(3 \mathrm{~d})$ after plating. We selected six areas within each well that contained at least 4000 cells each at $2 \mathrm{hr}$ after plating, counted the number of phase-bright cells within each area for each time point, and calculated the ratio of the number of phase-bright cells at each point in time to that at $2 \mathrm{hr}$ for each area. The results are given as the mean \pm SD of six areas. We repeated this experiment twice and got similar results. $B$, We plated GCPs from P11 p $27+/+, \mathrm{p} 27+/-$, or $\mathrm{p} 27-/-$ mice in Terasaki microculture plates, added MTT to the cultures at $0,1,2$, and $3 \mathrm{~d}$, randomly selected four areas in each well, counted all the cells (dead uncolored cells and live dark blue cells) within each area, and calculated the fraction of live cells. The results are given as the mean \pm SD of four areas. We repeated this experiment three times and got similar results.

p27-/ - cells survive better than the p27+/+ cells, we examined the survival of GCPs in culture using the MTT assay (live cells cleave the tetrazolium ring of MTT into a visible dark blue formazan reaction product, whereas dead cells remain uncolored). We plated GCPs from P11 p27+/+, p27+/-, or p27-/- mice in Terasaki microculture plates, added MTT to the cultures at $0,1,2$, and $3 \mathrm{~d}$, randomly selected four areas of the cultures, counted all of the cells (dead and live cells) within each area, and calculated the fraction of live cells. As we expected, there was no significant difference among the survival rates of the p27+/+ GCPs, the p27+/- GCPs, and the p27-/- GCPs (Fig. 8B).

\section{DISCUSSION}

The murine cerebellum contains $\sim 10^{8}$ granule cells, which is more than the number of neurons in the rest of the brain combined. How is this number of granule cells controlled? It seems likely that there are two mechanisms: control of the number of mature cells and control of the number of precursor cells.

It is widely accepted that cell death plays a crucial role in the 
control of the number of neurons (Oppenheim, 1991). According to the neurotrophic theory, neurons are produced in excess, and only those cells that succeed in making contact with their targets receive adequate amounts of neurotrophic factors, secreted by the target cells, and survive; the rest die by programmed cell death (Oppenheim, 1991). In accordance with this theory, we found many apoptotic cells in the GL of the developing cerebellum. We also observed many apoptotic cells in the superficial (proliferative) zone of the EGL, confirming previous reports (Tanaka and Marunouchi, 1998; Tanaka et al., 1998). The reason for these deaths remains to be determined.

GCPs, which are neuronal precursor cells, initially proliferate at the edge of the neuroepithelium (rhombic lip), where there is no overlying cellular structure, and then they stream up the lip rostrally and onto the surface of the cerebellar anlage, where they establish a displaced germinal zone, the EGL (Hatten and Heintz, 1995). After birth, rapid cell proliferation in the EGL expands the zone from a single cell layer to a layer that is eight cells thick. Precursor cell proliferation continues within the EGL until approximately P15, when the zone disappears owing to the inward migration of postmitotic cells to form the GL (Hatten and Heintz, 1995). The physiological mitogen for GCPs has long been unknown, although several growth factors have been reported to have a mitogenic effect on them in vitro (Gao et al., 1991; Lin and Bulleit, 1996; Tao et al., 1996; Ye et al., 1996). Recently, three groups independently reported that Purkinje cell-derived Shh regulates GCP proliferation in the developing cerebellum (Dahmane and Altaba, 1999; Wallace, 1999; Wechsler-Reya and Scott, 1999). In the present study, it was confirmed that Shh is a potent mitogen for GCPs. Recently, Yang and colleagues (1999) reported that overexpression of Zipro1 in vivo leads to an elevation in the number of cerebellar granule cells, and they suggested that its role is to increase the proliferative response of GCPs through an intrinsic cellular pathway that acts downstream of Shh. It has also been suggested that local homotypic interactions among GCPs stimulate their own proliferation (Gao et al., 1991). We observed constitutive proliferation of GCPs during the first day of dispersed monolayer culture and during the first $2 \mathrm{~d}$ of reaggregated cultures, in the absence of added growth factors, which supports this theory.

Whatever the physiological mitogen(s) for GCPs is, GCPs in vivo gradually exit the cell cycle and differentiate into mature granule cells. What stops GCP proliferation and allows the cells to differentiate into mature granule cells? In principle, cell proliferation is arrested during development either via a mechanism that is extracellular, such as a decrease in extracellular mitogen or an increase in extracellular inhibitor, or by an intracellular mechanism such as the activation of an intracellular stopping mechanism, the dismantling of the cell cycle control system, or some combination of these (Conlon and Raff, 1999). We found that GCPs in vitro stop proliferating even in the presence of saturating concentrations of Shh-N. GCPs from P3, P7, and P10 mice exited the cell cycle on approximately the 11 th, 7 th, and 4 th to 7 th day of dispersed monolayer culture, respectively. Most GCPs from P10 mice exited the cell cycle on about the fifth to sixth day of reaggregated culture. GCPs in vivo exit the cell cycle at around $\mathrm{P} 15$. Thus the normal timing of exiting of GCPs from the cell cycle was restored in vitro by Shh-N, as is the case for oligodendrocyte precursor cells; the normal timing of oligodendrocyte development is restored in vitro by platelet-derived growth factor (Raff et al., 1988). This result suggests that the intracellular mechanism that acts in oligodendrocyte development also acts in GCP differentiation. When we cultured reaggregated GCPs from $\mathrm{P} 10$ mice in the presence of Shh-N for $>5$ $\mathrm{d}$, the cells in most of the reaggregates did not take up BrdU, although we occasionally observed clusters of BrdU-positive cells within some of the reaggregates. Even after $10 \mathrm{~d}$ in culture, we still found reaggregates containing clusters of BrdU-positive cells, although only infrequently. Wechsler-Reya and Scott (1999) reported that cells from P8 mice grown in Shh-containing media for $14 \mathrm{~d}$ still showed substantial thymidine incorporation at the end of the culture period. Gao et al. (1991) also reported that GCPs continued to proliferate for $>20 \mathrm{~d}$ when cultured in cellular reaggregates in serum-supplemented media. It is possible that a small proportion of GCPs remain as self-renewing precursors and that the presence of Shh or being cultured in cellular reaggregates, or both, helps these cells to remain as such, whereas most GCPs eventually exit the cell cycle, even in the presence of mitogens.

In the present study, p27 was expressed by the GCPs in the inner two-thirds of the EGL of the developing cerebellum; cells in the deeper zone of the EGL expressed p27 more strongly than the cells in the middle zone. This finding suggests that p27 gradually accumulates in GCPs as they proliferate, rather than after they exit the cell cycle. Our observation that the cells in the middle of the EGL express not only p27 but also PCNA, a marker for proliferating cells, also supports the theory that GCPs gradually accumulate p27 as they proliferate. We also found that there is an inverse correlation between p 27 expression and BrdU incorporation by cultured GCPs. p27 is part of the intrinsic timer that determines when oligodendrocyte precursor cells stop dividing and differentiate (Durand et al., 1997, 1998), so p27 may play a similar role in the cerebellar granule cell lineage. Our findings that a minor portion of GCPs incorporated BrdU for longer periods than the majority of the cells, when cultured in reaggregates in the presence of Shh-N, and that these cells expressed p27 only weakly, suggest that these cells are self-renewing precursors that accumulate p27 only very slowly, if at all, as they proliferate.

In the present study, mature granule cells in the GL of the developing and adult cerebella strongly accumulated p27. This finding suggests that p27 keeps the mature granule cells in the quiescent postmitotic state, as has been shown for other cell types (Polyak et al., 1994; Slingerland et al., 1994; Casaccia-Bonnefil et al., 1997; Durand et al., 1997).

Watanabe and colleagues (1998) examined the expression of p27 in developing and adult cerebella and reported that p27 was present primarily in Purkinje cells. They also reported that p27 was not expressed in the EGL, within either the proliferating external zone or the inner postmitotic zone, and that only some of the mature granule cells in the GL expressed p27. They suggested that p27 levels are reduced in the adult cerebellum. On the basis of these findings, they argued that p27 is not involved in proliferative arrest of GCPs and that p27 is not required for the maintenance of the terminally differentiated neural phenotype. Their findings are significantly different from ours. The most likely explanation for this discrepancy is the difference in the techniques used. In early trials, we also observed weak p27 staining, primarily in the Purkinje cells. We then shortened the time for fixation in paraformaldehyde from 12 to $1 \mathrm{hr}$, extended the time for washing after paraformaldehyde, and used the microwave technique that has been shown to improve antigenicity in other cell types. We then observed much stronger signals.

Even GCPs from the p27-/- mice ultimately exited the cell cycle and differentiated into mature granule cells, indicating that p27 is not the sole component of the stopping mechanism. Our finding that GCPs continue to proliferate in the presence of Shh-N even when most of them strongly express p27 also suggests that accumulation of p27 alone is not enough to make them exit the cell cycle. In this study, we confirmed the previous finding that cyclin D1 is dismantled in mature granule cells (Shambaugh et al., 1996; Watanabe et al., 1998), so it is likely that the absence of cyclin D1, together with the presence of p27, prevents mature granule cells from reentering the cell cycle. Huard and colleagues (1999) reported that the number of granule cells was reduced in cerebella from mice lacking cyclin D2 and suggested that cyclin D2 is required for GCP proliferation. It remains to be determined, however, whether dismantling of cyclin D1 or D2 is part of the mechanism that results in proliferating GCPs exiting the cell cycle. It is possible that other $\mathrm{Cdk}$ inhibitors perform the function of $\mathrm{p} 27$ in the p27-/- cells, allowing the cells to stop dividing and to differentiate. We have examined the expression of p18, p21, and p57 in GCPs from p27-/- mice in culture and in frozen sections, but we did not see the upregulation of these Cdk inhibitors. We are 
now examining the expression of other Cdk inhibitors in the cerebella of p27-deficient mice.

In summary, our findings suggest that there is an intracellular mechanism that causes GCPs to stop dividing and that p27 is part of this mechanism. To our knowledge, this is the first report that suggests the existence of such a mechanism in a neuronal cell lineage. In the developing cerebral cortex, p27 is expressed strongly by the postmitotic neurons of the cortical plate and preplate but only weakly by proliferating neuroblasts in the ventricular zone (Lee et al., 1996). Whether these neuroblasts gradually accumulate p27 as they proliferate or whether they accumulate p27 after exiting the cell cycle is not known. It remains to be determined whether an intracellular cell cycle-exiting mechanism that is dependent on the accumulation of p27, which seems to be present in GCPs, also exists in these neuroblasts.

\section{REFERENCES}

Altman J, Bayer SA (1996) Development of the cerebellar system. Boca Raton, FL: CRC

Baptista CA, Hatten ME, Blazeski R, Mason CA (1994) Cell-cell interactions influence survival and differentiation of purified Purkinje cells in vitro. Neuron 12:243-260.

Casaccia-Bonnefil P, Tikoo R, Kiyokawa H, Friedrich Jr V, Chao MV, Koff A (1997) Oligodendrocyte precursor differentiation is perturbed in the absence of the cyclin-dependent kinase inhibitor p27Kip1. Genes Dev 11:2335-2346.

Conlon I, Raff M (1999) Size control in animal development. Cell 96:235-244.

Dahmane N, Altaba ARI (1999) Sonic hedgehog regulates the growth and patterning of the cerebellum. Development 126:3089-3100.

Durand B, Gao FB, Raff M (1997) Accumulation of the cyclin-dependent kinase inhibitor $\mathrm{p} 27 / \mathrm{Kip} 1$ and the timing of oligodendrocyte differentiation. EMBO J 16:306-317.

Durand B, Fero ML, Roberts JM, Raff MC (1998) p27Kip1 alters the response of cells to mitogen and is part of a cell-intrinsic timer that arrests the cell cycle and initiates differentiation. Curr Biol 8:431-440.

Fero ML, Rivkin M, Tasch M, Porter P, Carow CE, Firpo E, Polyak K, Tsai LH, Broudy V, Perlmutter RM, Kaushansky K, Roberts JM (1996) A syndrome of multiorgan hyperplasia with features of gigantism, tumorigenesis, and female sterility in p27(Kip1)-deficient mice. Cell 85:733-744

Gao WO, Heintz N, Hatten ME (1991) Cerebellar granule cell neurogenesis is regulated by cell-cell interactions in vitro. Neuron 6:705-715.

Gavrieli Y, Sherman Y, Ben-Sasson SA (1992) Identification of programmed cell death in situ via specific labeling of nuclear DNA fragmentation. J Cell Biol 119:493-501.

Harper JW, Elledge SJ (1996) Cdk inhibitors in development and cancer. Curr Opin Genet Dev 6:56-64.

Hatten ME, Heintz N (1995) Mechanisms of neural patterning and specification in the developing cerebellum. Annu Rev Neurosci 18:385-408.

Herrup K, Sunter K (1987) Numerical matching during cerebellar development: quantitative analysis of granule cell death in staggerer mouse chimeras. J Neurosci 7:829-836.

Huard JM, Forster CC, Carter ML, Sicinski P, Ross ME (1999) Cerebellar histogenesis is disturbed in mice lacking cyclin D2. Development 126:1927-1935.

Ishizaki Y, Voyvodic JT, Burne JF, Raff MC (1993) Control of lens epithelial cell survival. J Cell Biol 121:899-908.

Ishizaki Y, Jacobson MD, Raff MC (1998) A role for caspases in lens fiber differentiation. J Cell Biol 140:153-158.

Kiyokawa H, Kineman RD, Manova-Todorova KO, Soares VC, Hoffman ES, Ono M, Khanam D, Hayday AC, Frohman LA, Koff A (1996) Enhanced growth of mice lacking the cyclin-dependent kinase inhibitor function of p27(Kip1). Cell 85:721-732.

Lee MH, Nikolic M, Baptista CA, Lai E, Tsai LH, Massague J (1996) The brain-specific activator p35 allows Cdk5 to escape inhibition by p27Kip1 in neurons. Proc Natl Acad Sci USA 93:3259-3263.

Lees E (1995) Cyclin dependent kinase regulation. Curr Opin Cell Biol 7:773-780.

Lin X, Bulleit RF (1996) Cell intrinsic mechanisms regulate mouse cerebellar granule neuron differentiation. Neurosci Lett 220:81-84.

Matsuoka S, Edwards MC, Bai C, Parker S, Zhang P, Baldini A, Harper JW, Elledge SJ (1995) p57KIP2, a structurally distinct member of the
p21CIP1 Cdk inhibitor family, is a candidate tumor suppressor gene. Genes Dev 9:650-662.

Morgan DO (1995) Principles of CDK regulation. Nature 374:131-134.

Mosmann T (1983) Rapid colorimetric assay for cellular growth and survival: application to proliferation and cytotoxicity assays. J Immunol Methods 65:55-63.

Mullen RJ, Hamre KM, Goldowitz D (1997) Cerebellar mutant mice and chimeras revisited. Perspect Dev Neurobiol 5:43-55.

Nakayama K, Ishida N, Shirane M, Inomata A, Inoue T, Shishido N, Horii I, Loh DY, Nakayama K (1996) Mice lacking p27(Kip1) display increased body size, multiple organ hyperplasia, retinal dysplasia, and pituitary tumors. Cell 85:707-720.

Oppenheim RW (1991) Cell death during development of the nervous system. Annu Rev Neurosci 14:453-501.

Parker SB, Eichele G, Zhang P, Rawls A, Sands AT, Bradley A, Olson EN, Harper JW, Elledge SJ (1995) p53-independent expression of p21Cip1 in muscle and other terminally differentiating cells. Science 267:1024-1027.

Polyak K, Kato JY, Solomon MJ, Sherr CJ, Massague J, Roberts JM, Koff A (1994) p27Kip1, a cyclin-Cdk inhibitor, links transforming growth factor-beta and contact inhibition to cell cycle arrest. Genes Dev 8:9-22.

Raff MC, Lilien LE, Richardson WD, Burne JF, Noble MD (1988) Platelet-derived growth factor from astrocytes drives the clock that times oligodendrocyte development in culture. Nature 333:562-565.

Shambaugh 3rd GE, Lee RJ, Watanabe G, Erfurth F, Karnezis AN, Koch AE, Haines 3rd GK, Halloran M, Brody BA, Pestell RG (1996) Reduced cyclin D1 expression in the cerebella of nutritionally deprived rats correlates with developmental delay and decreased cellular DNA synthesis. J Neuropathol Exp Neurol 55:1009-1020.

Sherr CJ (1994) G1 phase progression: cycling on cue. Cell 79:551-555.

Sherr CJ, Roberts JM (1995) Inhibitors of mammalian G1 cyclindependent kinases. Genes Dev 9:1149-1163.

Slingerland JM, Hengst L, Pan CH, Alexander D, Stampfer MR, Reed SI (1994) A novel inhibitor of cyclin-Cdk activity detected in transforming growth factor beta-arrested epithelial cells. Mol Cell Biol 14:3683-3694.

Smeyne RJ, Chu T, Lewin A, Bian F, Crisman S, Kunsch C, Lira SA, Oberdick J (1995) Local control of granule cell generation by cerebellar Purkinje cells. Mol Cell Neurosci 6:230-251.

Sonmez E, Herrup K (1984) Role of staggerer gene in determining cell number in cerebellar cortex. II. Granule cell death and persistence of the external granule cell layer in young mouse chimeras. Brain Res 314:271-283.

Tanaka M, Marunouchi T (1998) Immunohistochemical analysis of developmental stage of external granular layer neurons which undergo apoptosis in postnatal rat cerebellum. Neurosci Lett 242:85-88.

Tanaka M, Sawada M, Miura M, Marunouchi T (1998) Insulin-like growth factor-I analogue prevents apoptosis mediated through an interleukin-1 beta converting enzyme (caspase-1)-like protease of cerebellar external granular layer neurons: developmental stage-specific mechanisms of neuronal cell death. Neuroscience 84:89-100.

Tao Y, Black IB, DiCicco-Bloom E (1996) Neurogenesis in neonatal rat brain is regulated by peripheral injection of basic fibroblast growth factor (bFGF). J Comp Neurol 376:653-663.

Vogel MW, Sunter K, Herrup K (1989) Numerical matching between granule and Purkinje cells in lurcher chimeric mice: a hypothesis for the trophic rescue of granule cells from target-related cell death. J Neurosci 9:3454-3462.

Wallace VA (1999) Purkinje-cell-derived Sonic hedgehog regulates granule neuron precursor cell proliferation in the developing mouse cerebellum. Curr Biol 9:445-448.

Watanabe G, Pena P, Shambaugh 3rd G, Haines 3rd G, Pestell RG (1998) Regulation of cyclin dependent kinase inhibitor proteins during neonatal cerebella development. Brain Res Dev Brain Res 108:77-87.

Wechsler-Reya RJ, Scott MP (1999) Control of neuronal precursor proliferation in the cerebellum by Sonic Hedgehog. Neuron 22:103-114.

Wetts R, Herrup K (1983) Direct correlation between Purkinje and granule cell number in the cerebella of lurcher chimeras and wild-type mice. Brain Res 312:41-47.

Yang XW, Wynder C, Doughty ML, Heintz N (1999) BAC-mediated gene-dosage analysis reveals a role for Zipro1 (Ru49/Zfp38) in progenitor cell proliferation in cerebellum and skin. Nat Genet 22:327-335.

Ye P, Xing Y, Dai Z, D'Ercole AJ (1996) In vivo actions of insulin-like growth factor-I (IGF-I) on cerebellum development in transgenic mice: evidence that IGF-I increases proliferation of granule cell progenitors. Brain Res Dev Brain Res 95:44-54. 